
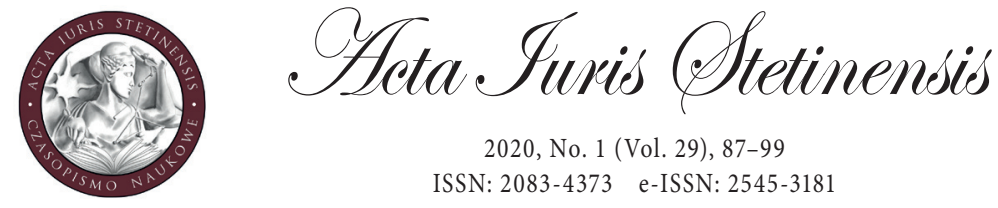

2020, No. 1 (Vol. 29), 87-99

ISSN: 2083-4373 e-ISSN: 2545-3181

DOI: $10.18276 /$ ais.2020.29-07

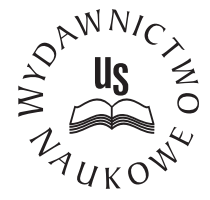

Oskar Kwasiński

Ph.D. student

University of Gdansk, Poland

Doctoral School of Humanities and Social Sciences

e-mail: kwasinski.law@gmail.com

OPEN ACCESS

ORCID ID: 0000-0002-8463-3280

\title{
RAM devices in the light of selected provisions of the Act on weapons and ammunition ${ }^{1}$
}

\begin{abstract}
The modern market for personal protection devices has brought about such challenges as the need to phrase legal regulations regarding possession and use of such devices. The aim of the study is to answer the questions whether RAM devices are firearms and whether they are weapons at all within the meaning of the Act of 21 May 1999 on weapons and ammunition. On the way to achieve this goal, a thorough analysis of the translation of the detailed characterisation of RAM devices into specific definitions of the Act in question is used. The result of the author's research is the conclusion that RAM devices are neither weapons nor firearms within the meaning of Polish legislation. Furthermore, the article provides a number of legal consequences resulting from such research conclusions, e.g. no obligation to undergo medical or psychological examinations by a potential RAM device owner.
\end{abstract}

Keywords: weapon, RAM, real action marker, firearms, ammunition

1 Act of 21 May 1999 on weapons and ammunition, consolidated text: Dz.U. (Journal of Laws) 2019, item 284, hereinafter: A.W.A 


\section{Introduction}

In recent years, the Polish market for broadly understood self-defence products has seen the emergence of real action markers, or devices which, at first sight, resemble firearms. Those RAM devices which accurately imitate, even if by their external appearance, specific firearm models can safely be termed as replicas ${ }^{2}$. The term device $e^{3}$ is used herein deliberately, for it is the most general and substantively cautious denomination for these types of objects, although their manufacturers and dealers refer to them as, among others, markers (thus suggesting a certain analogy with paintball markers), replicas (impliedly - firearm replicas) or even weapons (although this is surely an oversimplification). However, it would be wrong to define all RAM devices as replicas (indeed, not every such device is a replica of a specific firearm, which is best demonstrated by the example of the HDR 50 T4E), or to define RAM devices as:

- markers (RAM devices are not designed solely to mark targets, e.g. with paint, as is the case of paintball markers);

- or, the more so, weapons (as this term must be approached with particular caution).

The purpose of this paper is to answer the following two fundamental questions:

1. Are RAM devices firearms within the meaning of the Act of 21 May 1999 on weapons and ammunition?

2. Are RAM devices weapons at all within the meaning of the aforementioned Act? The layout of the paper may be puzzling, as the first of its goals is to answer the question of whether RAM devices are firearms and, only then, to answer the question of whether RAM devices are weapons at all. A negative answer to the

2 Replica meaning something which accurately imitates something else; a true copy - as in: Dubisz, S. (ed.), Uniwersalny słownik języka polskiego PWN, Warszawa 2006, p. 930.

3 Lexicographers state that a device is a mechanism or a set of mechanisms [...] designed to carry out specific activities, playing a certain function; an appliance - as in Dunaj, B. (ed.), Wspótczesny słownik języka polskiego. O-Ż, Warszawa 2007, p. 1926, and also a mechanism or a set of mechanisms designed to carry out specific activities to facilitate work; an instrument, a machine - as in Dubisz, S. (ed.), Wielki..., O-Ż, p. 102. It also seems that it would be advisable to use the term tool, which, according to the authors of dictionaries, means e.g. a simple or complex device which makes it possible to carry out a certain activity or work; an appliance, an instrument - as in Dubisz, S. (ed.), Wielki..., H-N, p. 1086, or an object which enables or facilitates execution of a certain piece of work, an appliance, an instrument - as in Dunaj, B., Wspótczesny..., pp. 928-929. One should note that lexicography most often highlights the work-related purpose of tools. Furthermore, the term device is purely intuitively associated with a broader scope of application than the term tool, which is normally understood as a means to carry out a certain work/a certain duty. Additionally, the term device was already used by the legislator in the Act on weapons and ammunition and was subsequently replaced by the term portable barrelled weapon. 
question of whether RAM devices are weapons at all would also, a maiori ad minus, ${ }^{4}$ be a negative answer to the question of whether RAM devices are firearms. Even a positive answer to the question of whether RAM devices are weapons at all would justify the layout of the article in which the question of whether RAM devices are weapons at all would be first. However, the layout of this study is not accidental. The justification for such a structure of the study is threefold. First of all - one should seek this justification in the specificity of social associations (the average person, unfamiliar with the subject of firearms, will especially associate RAM devices that are replicas of firearms from the outside with firearms). Secondly - belonging to the class of firearms is associated with much more significant legal consequences than it is in the case of the given item belonging to the class of weapons at all (a negative answer to the question about the belonging of RAM devices to the class of firearms could reassure readers who are potential buyers of RAM devices). Finally, the layout of the article, according to which the first is the question about whether RAM devices belong to the class of firearms is basically analogous in its consequences to the reverse structure of the study. A positive answer to the question about whether RAM devices belong to the class of firearms ends the discussion on whether RAM devices are weapons at all. A negative answer to the question about whether RAM devices belong to the class of firearms does not close the discussion on whether RAM devices are weapons at all.

Answering these questions will allow one to draw conclusions regarding the legal consequences of using such devices depending on whether or not they are weapons (and if yes, then what type of weapon). The necessary starting point for further reflections (including answering the above questions) will be a detailed characterisation of RAM devices, explaining the assumptions behind designing these devices, their mechanism of action and the materials which these devices can expel. This clarification is necessary, as it will constitute the basis for examining whether RAM devices can be categorised as weapons in the context of specific definition components included such provisions of the A.W.A as Article 4 and Article 7.

\section{Characteristics of RAM devices}

\section{Definition and purpose of RAM devices}

In Polish literature, finding attempts to define a RAM is a very difficult challenge. Therefore, one must rely on other sources in this respect. A real action marker

4 Argumentum a maiori ad minus (inference from larger to smaller) is a kind of so-called inference a fortiori. Inference a maiori ad minus can be presented using the example: Whoever is allowed more, all the more is allowed less - See: Morawski, L., Wstęp do prawoznawstwa, Torun 2008, p. 162. 
(RAM) is a paintball weapon powered by $\mathrm{CO}_{2}$ or compressed air, firing 0.43 caliber (0.43 inch or $10.9 \mathrm{~mm}$ ) paint-filled or rubber balls. ${ }^{5}$ According to another definition attempt, RAMs are simply advanced replicas (of firearms) which expel rubber, pepper, paint or powder bullets. ${ }^{6}$ Due to their concise character, among others, these specific definitions fail to clarify exactly how RAMs would differ from e.g. pneumatic weapons or firearms (if one assumes that RAMs are neither of the two). However, RAMs do share certain technical similarities with the aforementioned weapon types, as well as with the so-called paintball markers.

RAM devices which have been available on the Polish market in recent years have often been designated as T4E. The acronym stands for training for engagement, which is translated into Polish as trening nawiazywania walki $i^{7}$ or trening przez walke..$^{8}$ Such devices were originally manufactured for the training purposes of US uniformed services. The Americans needed devices which could be used in CQB (close quarters battle) drills, i.e. when firing shots at short distances in enclosed spaces. They needed a device which was safe to use and, at the same time, could expel projectiles with sufficient force to cause clear discomfort in counterpart trainees. These requirements were met by RAM T4E devices, which expelled safe, non-penetrating projectiles with kinetic energy sufficient to cause pain in humans and, at the same time, were accurate replicas of lethal firearms (also in terms of weight and use - bolt/slide operation, magazine loading, use of weapon sights, etc.). ${ }^{9}$ It is pointed out that RAM devices can be used, depending on the type of projectiles expelled, for such purposes as e.g. shooting practice, paintball or ASG recreation or personal protection. ${ }^{10}$ The latter clearly involves the possibility to use a RAM device in a situation of a threat to a legally protected asset - where it becomes necessary to use the benefits of such criminal law measures as the right of self-defence or the state of necessity. The intended purpose of the device in question defined in this manner seems to be most reliable and exhaustive.

5 AirsoftPRESS, The guide to maintaining and tuning a Real Action Marker (RAM) M4 Gearbox, Scotts Valley, p. 9.

6 Zastosowanie markerów RAM, Militaria.pl blog, https://militaria-blog.pl/samoobrona/zastosowanie-markerow-ram/ (accessed 5.03.2020).

7 Lewandowski, J., Walther PPQ na gumowe kule, 6.09.2017. strzał.pl pro liberate, https://strzal. pl/2017/09/06/walther-ppq-na-gumowe-kule/ (accessed 5.03.2020).

8 Ibidem.

9 Ibidem.

10 Ibidem. 


\section{Mechanism of action and the construction of RAM devices}

In RAM devices, the expelling mechanism itself is principally the same as that used in airguns. Indeed, RAM devices and airguns expel projectiles with the use of compressed air or carbon dioxide, which is subjected to mechanical pressure generated by internal mechanical components without any chemical reactions. It is therefore a completely different mechanism than that used in firearms, where a bullet is discharged as a result of exothermic oxidation of combustible propellants (discharge gases/propulsive gases) in a process that generates propulsive energy for the bullet. ${ }^{11}$ Obviously, both these processes are initiated by the action of the device's internal mechanical components operated by the user.

Although RAM devices which are manufactured and sold at present cannot be stripped in the same way as e.g. lethal firearms or popular airguns (i.e. pneumatic pistols and rifles which discharge pellets with kinetic energy up to $17 \mathrm{~J}$ ), one can say that their internal assembly corresponds to that of airguns. The internal design of airguns powered by 12 -gram $\mathrm{CO}_{2}$ capsules and that of RAM devices are very similar, as RAM devices are powered by 12 -gram $\mathrm{CO}_{2}$ capsules. The differences in the internal design of the two device types lie principally in the size of specific components, which is due to the different calibres of bullets which they expel. Naturally, the bolt section will be larger and the barrel wider in RAM devices, which expel 0.43 inch or 0.50 inch calibre bullets (ca. $10.9 \mathrm{~mm}$ and $11 \mathrm{~mm}$, respectively), than in airguns, which expel pellets of e.g. $4.5 \mathrm{~mm}$ calibre. However, one can say that in functional terms, both designs are principally analogous.

\section{Projectile expelled in RAM devices}

In the aforementioned cases of airguns and RAM devices, the kinetic energy of the bullet expelled is much lower than $17 \mathrm{~J}$. Importantly, RAM devices have been designed to expel only non-penetrating projectiles. Simply put, the shape of bullets expelled by a RAM device makes them unable to penetrate the target, e.g. a human body (unlike pointed and elongated bullets used in lethal firearms, whose penetrating properties are enhanced by the characteristics of the bullet discharge process itself). RAM devices expel only spherically-shaped bullets made of rubber, rubber with an admixture of steel or another soft material (in the case of bullets filled with paint, powder or capsaicin).

Although no empirical studies with RAM devices have been conducted yet to determine the consequences of firing a bullet from such a device at a human and the subsequent contact of the bullet with the human body, one must assume that

11 Campbell, R., Strzelanie z broni palnej. Ilustrowany podręcznik, Warszawa 2014, p. 13. 
the consequences for the potential target would not be severe. RAM devices expel spherically-shaped bullets made of relatively soft material, with low kinetic energy of 4-5 J. Furthermore, it seems that RAM devices are also much safer to use than airguns, which is mentioned on numerous occasions in this paper. Indeed, the latter, available on the Polish market, expel pellets - smelted metal products, normally with sharp edges. In addition, the pellets used in airguns are expelled with much greater kinetic energy (even up to ca. $11 \mathrm{~J}$ ) than in the case of bullets expelled by RAM devices (4-5 J). Due to the aforementioned factors, shooting airguns at live targets, e.g. humans, may cause various health-related consequences to the latter. The potential hazards related with shooting pneumatic weapons (including airguns, which in fact are such weapons) at live targets have also been highlighted by experts. ${ }^{12}$ However, one should not draw hasty conclusions from the above observations, such as a claim that airguns may not be used as a balanced means of defending legally protected assets in emergency situations.

\section{RAM devices in the light of definitions provided in the A.W.A.}

\section{Are RAM devices firearms?}

These deliberations, bearing critical importance for the subject matter of this paper, must be started by quoting a legal definition of the firearm in extenso. ${ }^{13}$ Article 7 section 1 of the A.W.A. stipulates that: Within the meaning of the Act, the term firearm shall mean every portable barrelled weapon which expels, is designed to expel or can be converted to expel one or more bullets or substances by the action of a propellant. In order to resolve whether RAM devices are firearms, one needs to closely examine whether they meet all the essential requirements set out in the aforementioned definition of what makes an object a firearm.

Firstly, one must state that in their efforts to resolve the meaning of the term firearm, the legislators explain that it is a [...] portable barrelled weapon without providing any prior concise explanation of what a weapon is in their opinion. It is not yet known whether RAM devices are weapons at all, but it is known that they are certainly portable barrelled devices. Hence, when analysing RAM devices or firearms, knowing that they are barrelled devices, one must make a preliminary assumption that they are also barrelled weapons. Adopting the opposite hypothesis

12 See: Bratton, S.L. et. al, Serious and fatal air gun injuries: more than meets the eye, "Pediatrics" 1997, No. 100(4), pp. 609-612; Shaw, M.D.M. and Galbraith, S., Penetrating airgun injuries of the head, "British Journal of Surgery" 1977, No. 64(3), pp. 221-224; Bowen, D.I. and Magauran, D.M., Ocular injuries caused by airgun pellets: an analysis of 105 cases, "Br Med J" 1973, No. 1(5849), pp. 333-337. 
would eliminate the necessity to analyse subsequent features of RAM devices on the grounds of further components of the definition of firearms in the meaning of Article 7 section 1 of the A.W.A.

Furthermore, it must be clearly stated that not only are RAM devices capable of expelling one or more bullets, they are simply designed to do so. It must be noted here that the multitude of expressions with the verb expel used by the legislator indicates that the legislator's probable intention was to assign a different meaning to each of them. Therefore, it seems that the word expels simply means that one of its functions is to expel, but it is not its sole purpose, the phrase is designed to expel means that it has been made with the sole purpose to expel, and the phrase can be converted to expel simply means that it can be altered in order to expel (the latter meaning is supported by the content of Article 7 section 1a of the A.W.A.). The aforementioned diversification of meaning is substantiated by the prohibition of the per non est interpretation. ${ }^{14}$ Indeed, if one assumes that e.g. expels means the same as is designed to expel, one would have to conclude that the legislator acted unreasonably by constructing a definition containing redundant terms. Furthermore, it must be noted that by phrasing the above differentiation in that exact manner, the legislator wrongly used inclusive disjunction (expressed in Polish by the conjunction $l u b$ ) for all the terms provided, instead of exclusive disjunction (expressed in Polish by the conjunction albo). ${ }^{15}$

A matter that may raise significant doubts, and therefore requires slightly more thorough consideration, is whether RAM devices expel bullets by the action of a propellant. If one examines the phrase by the action of a propellant, then one may conclude that the said action of the propellant can be both combustion of a propellant and pressure of gasses - e.g. $\mathrm{CO}_{2}-$ as the two processes generate the propulsive force for the bullet. Consequently, one would have to consider, also based on other analyses made earlier in this paper, that RAM devices are not only barrelled weapons designed to expel one or more bullets, but also that the process of expelling is triggered by the action of a propellant, ergo ${ }^{16}$ RAM devices are firearms. However, it is doubtful whether gas, e.g. carbon dioxide, can be deemed as a propellant within the meaning of the regulation in question, and whether mechanical com-

14 The prohibition of interpretation per non est is a directive of the linguistic interpretation of law, according to which it is not allowed to interpret legal provisions so that certain parts of these provisions turn out to be redundant - See: Morawski, L., op. cit., p. 146.

15 The alternative is one type of sentence in a logical sense. The cumulative alternative is marked in Polish with the conjunction $l u b$; a disjunctive alternative is marked in Polish with the conjunction albo. The cumulative alternative can be represented by the sentence: $A$ lub $B$, which means: $A, B, A+B$. The disjunctive alternative can be represented by the sentence: $A$ albo $B$, which means: A, B. - See: Ziembiński, Z., Logika praktyczna, Warszawa 2019, p. 87.

16 Eng. thus. 
pression can be deemed as the action. It must be remembered that the regulation does apply to firearms. The prefix fire- suggests a specific process - oxidation of, importantly, a specific substance. Such reasoning is intensified by an analysis of the term ammunition in light of the A.W.A. The said Act stipulates in Article 4 section 2 that all references to ammunition shall mean references to firearm ammunition. An important feature of ammunition, indicated in Article 5 section 3 of the A.W.A., is that it has a primer which initiates combustion of the propellant, which is very aptly pointed out by R. Rejmaniak, ${ }^{17}$ who, equally aptly, suggests that the content of Article 7 section 1 of the A.W.A. lacks the word explosive preceding the term propellant. ${ }^{18} \mathrm{Had}$ it defined firearms in this manner, the legislator would have saved the addressees of the Act any reasonable doubts regarding what is and what is not legally deemed a firearm.

In conclusion, it must be clearly said that RAM devices are not firearms. It is true that it has been assumed that they are barrelled weapons, and, furthermore, they are designed to expel one or more bullets. However, the process of expelling involves the purely mechanical process of gas compression (e.g. $\mathrm{CO}_{2}$ ), not a chemical reaction of oxidation of a combustible propellant triggered by the impact of a firing pin on a cartridge's primer with a propellant charge ${ }^{19}$. Thus, RAM devices do not meet the third requirement of all the requirements necessary to deem them as firearms within the meaning of the A.W.A. RAM devices are neither a maiori ad minus signal firearms (Article 7 section 2 of the A.W.A.) nor alarm firearms (Article 7 section 3 of the A.W.A.).

\section{Are RAM devices weapons at all?}

It can be said that Article 4 section 1 of the A.W.A., by continuing the catalogue of objects that are weapons under the A.W.A., also creates an extensional legal definition of the term weapon. Furthermore, based on the position taken by the Supreme Court, one could consider it to be an extensional definition with a closed catalogue. Indeed, the Supreme Court concluded that an authentic baseball bat is not the tool defined in the last sentence of Article 4 section 1 point 4 a of the A.W.A. (i.e. a replica of a baseball bat)..$^{20}$ Thus, only objects listed in the catalogue in Article 4 section 1 of the A.W.A. may be deemed as weapons (in the legal meaning of the word).

17 Rejmaniak, R., Pojęcie broni palnej, "Prokuratura i Prawo" 2018, No. 4, pp. 78-103.

18 Ibidem.

19 Ciepliński, A., Encyklopedia współczesnej broni palnej (od połowy XIX wieku), Warszawa 1994, p. 89.

20 Resolution of the Supreme Court of 24 July 2001, I KZP 10/01, OSNKW 2001, No. 9-10, item 76. 
The Polish Language Dictionary defines weapon as inter alia a tool of combat and a means or a method of fighting against somebody or something. ${ }^{21}$ In accordance with this very general definition, items deemed as weapons can be not only the objects listed by the legislator in Article 4 section 1 of the A.W.A., e.g. incapacitating gas sprays and knuckle dusters, or objects which are intuitively associated with the term weapon, e.g. firearms, but also all other objects suitable for combat in any way whatsoever ${ }^{22}$. Such reasoning would be wrong, however, for then e.g. a toothpick, a ballpoint pen or footwear could also be deemed as weapons. The Court of Appeals in Łódź concluded that since the term weapon in Polish means, among others, arms or a tool of combat, then this explication can lead to the requirement of a certain abstract minimal level of threat to one's health or life which an object should meet to be deemed as a weapon. ${ }^{23}$ One must admit that this is a questionable conclusion. Following this reasoning, one could deem as a weapon everything which bears even a minimal threat potential - e.g. a nearly empty handbag used by a woman in defense against an attacker which, when used skilfully, can give the attacker several very superficial bruises. R. Rejmaniak ${ }^{24}$ seems to take a similar position to that taken by the Court concerned.

The suggestion that such, and not other, objects are covered by the definition of a weapon provided in Article 4 section 1 of the A.W.A. because firstly - they can serve as a tool of combat, and secondly - they are characterised by a certain generally understood minimal level of threat to health and life, is inconsistent and therefore could be wrong. Had such reasoning been rooted in logic, why then did the legislator not enumerate such objects in Article 4 section 1 of the A.W.A. as e.g. the aforementioned toothpick or scissors or an axe? Indeed, they all meet both of the presumed characteristics of a weapon. Secondly, the reasoning is also wrong, because in its definition of a weapon (Article 4 section 1 of the A.W.A.), the legislator indicates e.g. pneumatic weapons as weapons which expel bullets with kinetic energy greater than $17 \mathrm{~J}$. Returning to the earlier deliberations, it must be remembered that even an airgun expelling pellets with kinetic energy of $7.5 \mathrm{~J}$ can penetrate the human skull (and therefore cause a threat to life and health that is much greater

21 “Broń", Słownik Języka Polskiego, SJP PWN, https://sjp.pwn.pl/slowniki/broń.html (accessed 7.03.2020).

22 The term combat is construed very extensively and vaguely - as inter alia a struggle between opponents - as in "walka", Stownik Języka Polskiego, SJP PWN, https://sjp.pl/walka (accessed 8.03.2020).

23 Judgement of the Court of Appeals in Łódź of 14 June 2018, II AKa 111/18, OSAŁ 2018, No. 2, item 87.

24 Rejmaniak, R., op. cit., p. 98. 
than just minimal) ${ }^{25}$. This could indicate an intention, which the legislator relied upon when creating the catalogue in Article 4 section 1 of the A.W.A., to be guided rather by the criterion of abstractly average rather than abstractly minimum risk to life and health. Therefore, it seems that Z. Wardak and P. Grzegorczyk are closer to the truth, for they point out that weapons deemed as firearms should be those which, while keeping firearm-specific characteristics (such as firing a bullet by the force of gases from oxidation of a propellant), are also characterised by the capability to cause death or severe injuries. ${ }^{26}$ The phrase could indicate an intention not indicates an intention was used intentionally, because the legislator is inconsistent in putting together, in its definition, such objects as signal firearms (not intended as a tool of combat at all) with pneumatic weapons which discharge bullets with kinetic energy greater than $17 \mathrm{~J}$ (and are therefore capable of causing severe injuries to the target, or even capable of causing any minor injuries). Thus, it remains unknown what guided the legislator when creating Article 4 section 1 of the A.W.A. Nevertheless, it was certainly not the criterion of an object's abstractly minimal threat level to life and health.

RAM devices, as not being firearms (which has been resolved above in this paper), do not classify as any of the weapon types listed by the legislator in Article 4 section 1 of the A.W.A. Or do they? Article 8 of the A.W.A., which enacts the legal definition of pneumatic weapon, actually enumerates three constitutive characteristics of this weapon type, namely:

- threat to life or health;

- capability to discharge a bullet from a barrel or its substitute by the action of compressed gas, and thus the ability to engage targets at a distance;

- capability to discharge a bullet with kinetic energy greater than $17 \mathrm{~J}$.

Although RAM devices do in fact generally have the pneumatic mechanism referred to by the legislator in Article 8 of the A.W.A., only devices capable of discharging bullets with kinetic energy greater the $17 \mathrm{~J}$ may be categorised as pneumatic weapons ${ }^{27}$. As highlighted throughout this paper, RAM devices discharge bullets with kinetic energy of ca. 4-5 J. Therefore, they do not meet the energy criterion. Furthermore, since even an airgun, which discharges a bullet with kinetic energy of $7.5 \mathrm{~J}$, capable of penetrating the human skull, is not deemed by the legislator as dangerous to life or health, then a maiori ad minus a RAM device cannot be deemed

25 Laudański, R., Czy Polacy chca mieć dostęp do broni? [sonda], 12.08.2015, "Gazeta Pomorska", https://pomorska.pl/czy-polacy-chca-miec-dostep-do-broni-sonda/ar/77744449 (accessed 8.03.2020).

26 Grzegorczyk, P. and Wardak, Z., Pojęcie broni palnej w prawie karnym, "Prokuratura i Prawo" 2017, No. 10, pp. 85-99.

27 See: Kurzępa, B., Ustawa o broni i amunicji. Komentarz, Warszawa 2010, Legalis. 
as such. This argument is intensified by the view taken by the Court of Appeal in Wrocław that an A3000 pneumatic pistol is not as dangerous as a firearm or a knife $\mathrm{e}^{28}$ (assuming implicite ${ }^{29}$ that no object with a threat potential lower than a firearm or a knife should be deemed as a weapon). Apart from the above legislative and juristic deliberations, one must say that, objectively, RAM devices carry a negligible potential of threat to health and life, even if only due to the fact that they expel non -penetrating bullets with low kinetic energy. Simply put, RAM devices meet just one of the three requirements necessary to deem them as pneumatic weapons.

\section{Conclusions}

Answering the questions asked at the introduction of this paper, and thus meeting the purpose of the publication, one must say that RAM devices are not firearms, pneumatic weapons or can be legally understood weapons at all. This is so for two reasons:

- they do not meet all the requirements which they would have to meet to be categorised as firearms, pneumatic weapons or any other weapon type under Article 4 section 1 of the A.W.A.;

- they do not have a level of threat to life or health that would be sufficient to deem them as weapons (although they can be used in combat - e.g. in self defence against an attacker).

Naturally, the above state of affairs gives rise to specific legal consequences (not only under the A.W.A.). For a start, one needs to conclude that since RAM devices are not weapons, then their purchase, possession and sales are not forbidden ( c contrario $^{30}$ Article 2 of the A.W.A.). Although conversions of RAM devices which alter their intended purpose cannot be deemed as weapon manufacturing in the light of Article 6 of the A.W.A., such a conversion should in fact be deemed as weapon manufacturing if it is meant to e.g. convert a RAM device into a device expelling bullets with kinetic energy greater than $17 \mathrm{~J}$ (and thus making it a pneumatic weapon within the meaning of the A.W.A.). Not deeming RAM devices as firearms, pneumatic weapons or any weapons at all also brings a natural effect of the lack of the requirement to obtain a licence for and to register such a device (a contrario Article 9 of the A.W.A.). In addition, purchasing projectiles for RAM

28 Judgement of the Court of Appeals in Wrocław of 23 November 2005, II AKa 290/05, Legalis No. 77470.

29 Eng. implicitly.

30 Inference a contrario is the so-called inference from the opposite. This means that if the given legal consequences of $\mathrm{X}$ are related to the facts of $\mathrm{Z}$, then the legal consequences of $\mathrm{X}$ cannot be associated with the facts of $\mathrm{Y}$, even if the facts of $\mathrm{Y}$ are substantially similar to the facts of $\mathrm{Z}$ - see: Morawski, L., op. cit., p. 161. 
devices in the form of spherical bullets is not subject to any specific requirements such requirements have been established only for purchasing firearms ammunition (Article 14 in connection with Article 4 section 2 of the A.W.A.). Naturally, a person who intends to purchase a RAM device is not subject to an obligatory medical or mental examination, contrary to persons who apply for a firearms licence (Article $15 \mathrm{ff}$ of the A.W.A.). Neither is a potential owner of a RAM device obliged to take any exams in the knowledge of regulations regarding possession and use of RAM devices or in skills associated with the operation of RAM devices (a contrario Article 16 of the A.W.A.). This is, however, relatively general knowledge that exists in the public awareness somewhat intuitively. Therefore, it is necessary to proceed to slightly less obvious regulations.

In the event of losing a RAM device, its owner is not obliged to report it to the Police or Military Police (a contrario Article 25 of the A.W.A.). The same applies if the owner of a RAM device changes his or her place of permanent residence. Importantly, RAM device owners are not subject to a number of obligations regarding storage, carrying and transport of weapons (Articles 32 and 33, Chapter III of the A.W.A.). Therefore, a RAM device owner is allowed to travel by e.g. tram, bus or train with a loaded RAM device, even if it is ready to be discharged only by a simple pull on the trigger. ${ }^{31}$ Perhaps the most interesting consequence of not deeming RAM devices as weapons is that they do not have to be used for sports or training purposes at firing ranges only. As rightly pointed by S. Maj, the use of airguns - which are not deemed as weapons within the meaning of the A.W.A. either - is not restricted solely to firing ranges. ${ }^{32}$ However, it does not exclude the general liability for causing damage to other persons as a result of such devices. ${ }^{33}$ The same type of liability will emerge in the case of RAM devices. As a result, a RAM user is not subject to any specific liability for a crime or an offence under Chapter V (Articles 50 and 51) of the A.W.A. It also seems that RAM devices will not constitute another similarly dangerous object or a means of incapacitation within the meaning of Article $280 \$ 2$ of the Criminal Code, ${ }^{34}$ for their normal use (or any abnormal use, however understood) does not result in the threat of causing death or serious injury. ${ }^{35}$

31 S. Maj points out that the minimum secure condition for a weapon, as specified in Article 35 of the A.W.A., means carrying it without a cartridge in the chamber and with the safety lever on - see: Maj, S., Ustawa o broni i amunicji. Komentarz, Warszawa 2010, LEX.

32 Ibidem.

33 Ibidem.

34 Act of 6 June 1997 on the Criminal Code, consolidated text: Dz.U. (Journal of Laws) 2019, item 1950.

35 See: Decision of the Supreme Court of 29 May 2003, I KZP 13/03, OSNKW 2003, No. 7-8, item 69; Judgement of the Court of Appeals in Katowice of 12 April 2018, II AKa 56/18, LEX No. 2612788. 


\section{References}

AirsoftPRESS, The guide to maintaining and tuning a Real Action Marker (RAM) M4 Gearbox, Scotts Valley 2011.

Bowen, D.I. and Magauran, D.M., Ocular injuries caused by airgun pellets: an analysis of 105 cases, "Br Med J" 1973, No. 1(5849).

Bratton, S.L. et al., Serious and fatal air gun injuries: more than meets the eye, "Pediatrics" 1997, No. 100(4).

Campbell, R., Strzelanie z broni palnej. Ilustrowany podręcznik, Warszawa 2014.

Ciepliński, A., Encyklopedia współczesnej broni palnej (od połowy XIX wieku), Warszawa 1994.

Dubisz, S. (ed.), Uniwersalny słownik języka polskiego PWN, Warszawa 2006.

Dubisz, S. (ed.), Wielki słownik języka polskiego, H-N, Warszawa 2018.

Dubisz, S. (ed.), Wielki słownik języka polskiego, U-Ż, Warszawa 2018.

Dunaj, B. (ed.), Współczesny słownik języka polskiego, A-N, Warszawa 2007.

Dunaj, B. (ed.), Współczesny słownik języka polskiego, O-Ż, Warszawa 2007.

Grzegorczyk, P. and Wardak, Z., Pojęcie broni palnej w prawie karnym, "Prokuratura i Prawo" 2017, No. 10.

Laudański, R., Czy Polacy chca mieć dostęp do broni? [sonda], 12.08.2015, "Gazeta Pomorska”, https://pomorska.pl/czy-polacy-chca-miec-dostep-do-broni-sonda/ar/7774449.

Kurzępa, B., Ustawa o broni i amunicji. Komentarz, Warszawa 2010.

Maj, S., Ustawa o broni i amunicji. Komentarz, Warszawa 2010.

Morawski, L., Wstęp do prawoznawstwa, Toruń 2008.

Rejmaniak, R., Pojęcie broni palnej, "Prokuratura i Prawo" 2018, No. 4.

Shaw, M.D.M. and Galbraith, S., Penetrating airgun injuries of the head, "British Journal of Surgery" 1977, No. 64(3).

Ziembiński, Z., Logika praktyczna, Warszawa 2019.

\section{CITATION}

KWASIŃSKI, O., RAM devices in the light of selected provisions of the Act on weapons and ammunition, "Acta Iuris Stetinensis" 2020, No. 1 (Vol. 29), 87-99,

DOI: 10.18276/ais.2020.29-07. 